\title{
L-Carnitine Contents in the Tissues of Rabbits Fed Urea as an Alternative of Dietary Protein
}

\author{
Seizi Sukemori' ${ }^{1}$, Satoshi Odo ${ }^{2}$ \\ ${ }^{1}$ Faculty of Agriculture, Tokyo University of Agriculture, Atsugi City, Japan \\ ${ }^{2}$ Graduate School of Engineering, Tokyo University of Agriculture and Technology, Koganei City, Japan \\ Email: sukemori@nodai.ac.jp
}

How to cite this paper: Sukemori, S. and Odo, S. (2017) L-Carnitine Contents in the Tissues of Rabbits Fed Urea as an Alternative of Dietary Protein. Open Journal of Animal Sciences, 7, 1-7.

http://dx.doi.org/10.4236/ojas.2017.71001

Received: August 24, 2016

Accepted: December 4, 2016

Published: December 7, 2016

Copyright $\odot 2017$ by authors and Scientific Research Publishing Inc. This work is licensed under the Creative Commons Attribution International License (CC BY 4.0).

http://creativecommons.org/licenses/by/4.0/

cc) (i) Open Access

\begin{abstract}
The present study was aimed to observe the effects of urea ingestion, non-protein nitrogen, on the disorder of nitrogen metabolism with the L-carnitine contents using the blood, kidney, liver, and femoral muscle as markers. A total of 8 Japanese white rabbits were used in this experiment. They were fed a basal diet prepared for the control group and the nitrogen volume proportionated to one-third of CP $14 \%$, was replaced with urea in the feed of the experimental group for 7 days. On the final day, the animals were fasted from the previous evening and sacrificed. Blood was collected into a test tube at the same time of the sacrifice and their heart, kidney, liver and femoral muscle were collected. The L-carnitine contents in each sample and the urea in the blood were determined. The results of the growth test showed that there was no significant difference. Furthermore, there was no significant difference in the contents of L-carnitine and urea in each sample. It was concluded that nitrogen replacement of the diet with urea, in the range of $1 / 3$ of dietary protein, had neither effect on the maintenance of body weight nor nitrogen balance, including the de novo synthesis of L-carnitine.
\end{abstract}

\section{Keywords}

Rabbit, L-Carnitine, Urea, Replacement of Nitrogen

\section{Introduction}

L-Carnitine has an important role in the transport of fatty acids into mitochondria, which converts the fatty acids into energy in the various cells. In the previous reports, authors proposed that L-carnitine supplementation equalized unbalanced fatty acid degradation that is enhanced by exercise [1] [2]. However, it is well known that plants have low levels of L-carnitine, that animals synthesize L-carnitine from methionine and/or lysine as precursors and that there is a localization of L-carnitine content in the tissues, according to the differences in the tissue's function. Furthermore, L-carnitine 
contents varied according to the energy intake within a tissues group [3].

The fermentation by microorganisms in the digestive tract contributes to the nutritional metabolism of mammals, and coprophagy plays an important role thorough the re-ingestion of nutrients typified by amino acids and/or vitamins [4] [5] [6] synthesized by microorganism. Microorganism can synthesize amino acids with non-protein nitrogen in the digestive tracts and the contents in the re-ingested feces preserve it in the dietary status. Early reports suggested that rabbits could use protein synthesized by microorganisms as a body protein and they could show smooth growth as a result [7], but the L-carnitine content of tissues has never been determined under those condition.

The present study aimed to evaluate the effect of urea ingestion as a non-protein nitrogen source, which could induce a disorder of nitrogen metabolism, on the L-carnitine contents of various tissues.

\section{Materials and Methods}

\subsection{Animals and Diets}

A total of 8 Japanese white rabbits including two 46-month-old and six 14-month-old rabbits were used in this experiment. The rabbits were housed individually in dormitory-type cages. A daily 12-h light/dark cycle, an environmental temperature of $21^{\circ} \mathrm{C} \pm$ $3{ }^{\circ} \mathrm{C}$ and $60 \%$ relative humidity were maintained throughout the trial period. The diet was prepared in accordance with the feeding standard by the National Research Council (1977) [8]. For the experimental group, the feed content of nitrogen proportionated to $1 / 3$ of CP $14 \%$ was replaced with urea. The contents of the diet are shown in Table 1 . The animals consumed the diet in a pellet form under ad libitum conditions.

\subsection{Experimental Design and Methodology}

The rabbits were assigned to one of two groups with age and body weight matching. The control group included 4 rabbits receiving no replacement diet, and the other 4

Table 1. Composition (\%) of diets.

\begin{tabular}{ccc}
\hline & Control & Experiment \\
\hline Corn & 11.00 & 20.50 \\
Timothy & 26.80 & 39.63 \\
Alfalfa & 19.00 & 7.67 \\
Wheat bran & 7.00 & 1.00 \\
Barley & 26.00 & 28.00 \\
Soybean meal & 9.50 & 0.75 \\
NaCl & 0.50 & 0.50 \\
Urea & 0.00 & 1.75 \\
Vitamin ADE mix & 0.10 & 0.10 \\
Vitamin B mix & 0.10 & 0.10
\end{tabular}

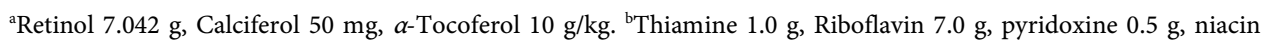
amide $6.0 \mathrm{~g}$, d-Pantothenic acid calcium $10.9 \mathrm{~g}$, Choline chloride $57.6 \mathrm{~g} / \mathrm{kg}$. 
rabbits in the experimental group received a diet replacing 1/3 of CP nitrogen with urea for 7 days. Feed intake and the body weight were determined daily and on the first and final days. On the final day, the animals were fasted overnight, and they were sacrificed. Blood was collected into test tubes at that time and their kidney, liver and femoral muscle were collected. The blood plasma was prepared from the whole blood by moderate centrifugation $(1500 \times \mathrm{g})$ and stored at $-40^{\circ} \mathrm{C}$ for the determination of urea and L-carnitine contents. After the organs and tissues were washed with isotonic saline $(0.85 \%$ $\mathrm{NaCl}$ ), the weight was determined and they were stored at $-40^{\circ} \mathrm{C}$.

The animals used in this study were cared for in accordance with the guideline of the Animal Welfare Act of Tokyo University of Agriculture.

\subsection{Analysis}

Initially, each $1 \mathrm{~g}$ of stored organs or tissues was dissolved in $6 \mathrm{~mL}$ of $2 \mathrm{M} \mathrm{KOH}$ solution for $120 \mathrm{~min}$ at $50^{\circ} \mathrm{C}$. The same volume of $2 \%$ sulfo-salicylic acid solution was added to the stored blood plasma and dissolved the solution of organs or tissues for the removal of protein sediments. The L-carnitine in the supernatant of the organ or tissue samples were determined under UV $21 \mathrm{~nm}$ by liquid chromatography (LC-20AD, Shimadzu, Co. Ltd., Kyoto, Japan) and the following conditions: a Unison UK-C18 column, $20 \mathrm{nM}$ phosphate buffer, including a $5 \mathrm{nM}$ octane sulfonic acid sodium carrier, and a flow rate of $0.8 \mathrm{~mL} / \mathrm{min}$. For the determination of the L-carnitine content in organs or tissues, the samples were diluted 50 times. The urea content in the blood plasma was determined using a UV spectrophotometer (UV-1800, Shimadzu, Co., Ltd., Kyoto, Japan) with a determination kit (Funakoshi, Co., Ltd., Tokyo, Japan)

\subsection{Statistics}

The results were statistically analyzed with one-way analysis of variance at a significance level of $\mathrm{P}<0.01$. The values are expressed as the means \pm standard error.

\section{Results}

\subsection{Results of Growth Test}

The chemical composition of the diet used in this study is shown in Table 1. Mean feed intake and body weight gain for both groups are shown in Table 2 . There is no significant difference in comparison of body weight gain, while the feed intake in the experimental group is lesser than that of the control group.

\subsection{L-Carnitine Contents of Blood, Organ and Tissue}

Blood L-carnitine contents (mg per liter) are as follows: control group $17.6 \pm 2.5$ and

Table 2. Results of growth test.

\begin{tabular}{cccc}
\hline & Control & Experiment & Significance \\
\hline Feed intake (g/7 days) & $93.6 \pm 4.2$ & $110.1 \pm 2.3$ & $0.05<\mathrm{P}<0.01$ \\
Body weight gain (g/7 days) & $31.3 \pm 5.2$ & $21.0 \pm 3.6$ & NS \\
\hline
\end{tabular}

Number of duplicates is 4 in each group. Mean \pm SE. 
experimental group $15.8 \pm 3.1$ (Figure 1). The L-carnitine contents $(\mathrm{mg} / \mathrm{kg}$ ) of the control and experimental groups are as follows: in kidney, $268 \pm 90$ and $630 \pm 109$, respectively; in liver, $1376 \pm 261$ and $1753 \pm 369$, respectively; and in femoral muscle, $7268 \pm$ 2208 and $5067 \pm 1538$, respectively (Figure 2). While the contents of each organ and tissue showed differences in the nitrogen replacement, there is no significant difference in the statistical treatment.

\subsection{Urea Contents of Blood}

The urea content $(\mathrm{mg} / \mathrm{mL})$ of the control group is $36.3 \pm 2.7$ and $34.6 \pm 2.2$ for the experimental group, as shown in Figure 3. There is no significant difference between groups.

\section{Discussion}

There are some reports related to the roles of L-carnitine in rabbit tissues, and most of them reveal its role in energy production with the supplement method. Casillas and Chaipayungpan [9] reported the carnitine contents of epididymal spermatozoa in an organ culture containing $25 \mathrm{mM}$ of L-carnitine, and they proposed that the accumulation of carnitine supported sperm maturation; however, there are few reports on the natural contents in rabbit tissues and/or organs. Madeleine [10] reported the L-carnitine contents of rabbit muscle and liver as food for humans. The present values are larger than the previous study, and this difference may be caused by the difference in

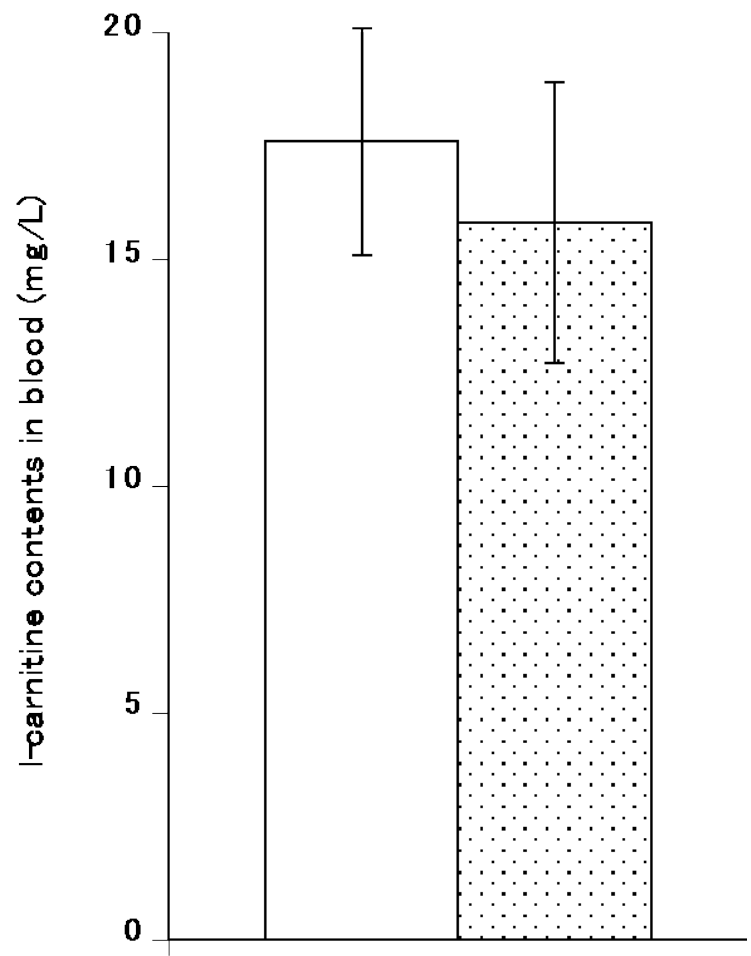

Figure 1. L-carnitine content in the blood. White = control, spotted $=$ experiment. The vertical bars represent the standard error. The number of duplicates is 4 in each group. 


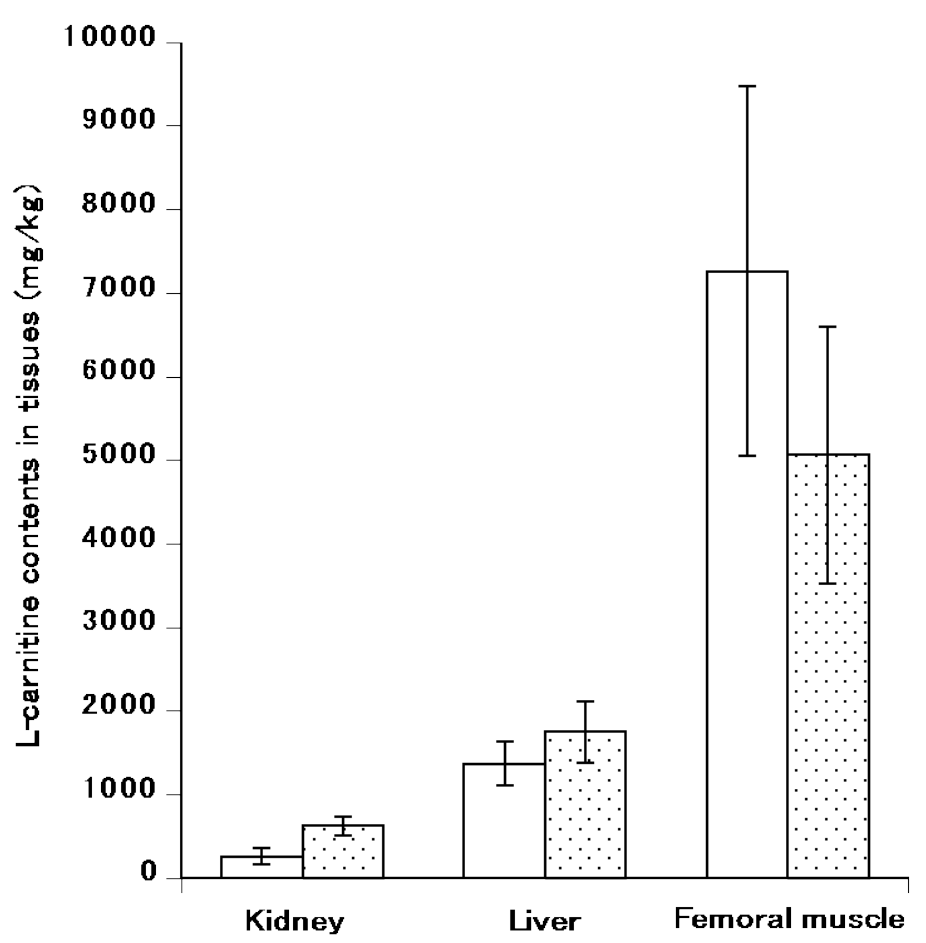

Figure 2. L-carnitine content in the objective tissues. White = control, spotted $=$ experiment. The vertical bars represent the standard error. The number of duplicates is 4 in each group.

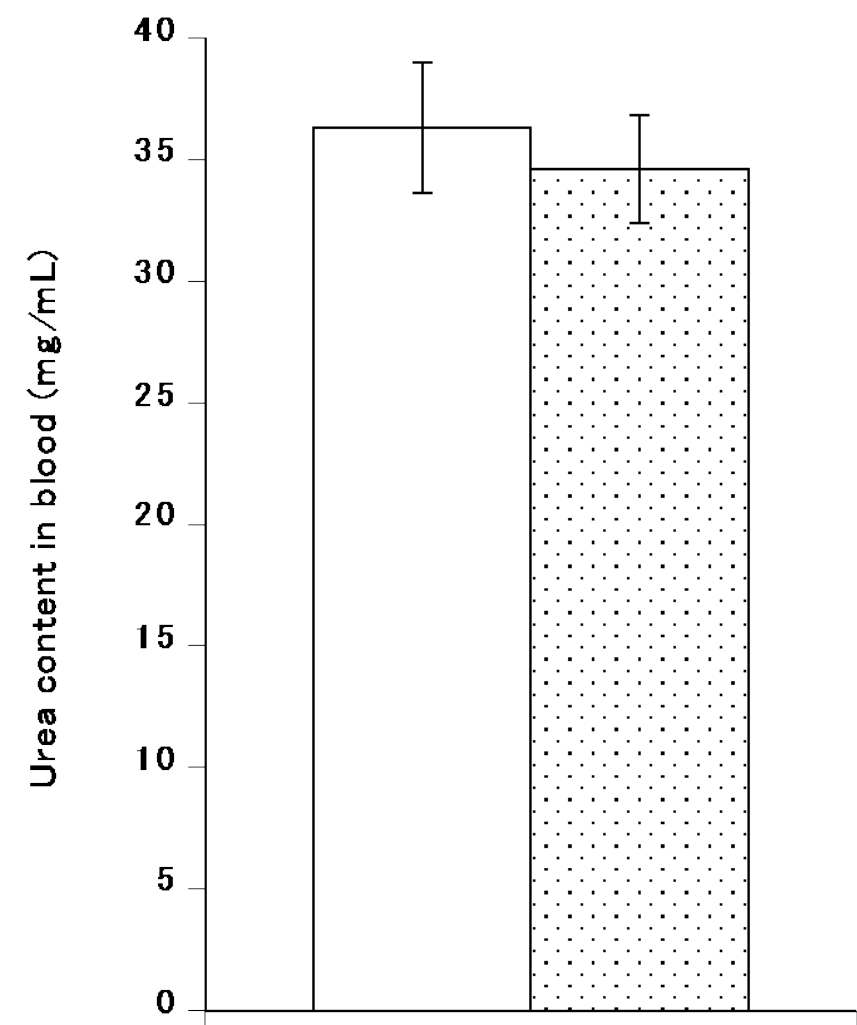

Figure 3. Urea content in the blood. White $=$ control, spotted $=$ experiment. The vertical bars represent the standard error. The number of duplicates is 4 in each group. 
the assay employed. Curto et al. [11] reported on the change in carnitine levels of various tissues in accordance with the development of the rabbit. They determined the total acid soluble carnitine, free carnitine, and short chain esterified carnitine in the liver, heart, skeletal muscle, and brain at fetal, birth (0-day), 5-day old, 15-day old, and 180-day old rabbits. The results showed that the value after birth (0-day) differed from the values of the before stages in total acid soluble carnitine, whereas the values of skeletal muscle were stable. Although the rabbits were of a different age, this study showed that the L-carnitine level was considerably stable.

The present study aimed to compare the effect of urea ingestion on the L-carnitine contents of the various tissues. Urea is a potent source in the feedstuff of ruminant and hindgut fermenting animals as an improvement of fiber digestibility and/or a direct supplement of nitrogen. An improvement in the nutritional value of crop residue treated with urea has been reported by several researchers with rabbits [12] [13] [14]. The present results of growth tests agreed with the results in the earlier reports [7] [14]. The main effect of the replacement of the nitrogen source on the growth performance of rabbits was not found, and the following amino acid imbalance, which was caused by the disorder of the amino acid pool in the blood and organs, may change the L-carnitine contents. L-Carnitine is not present in the composition of the test diet; therefore, the stable contents of L-carnitine in various tissues were maintained by the de novo synthesis in the disorder amino acid metabolism. According to the difference of L-carnitine contents in various tissues/organs, Madeleine [10] concluded that the L-carnitine content was highest in the muscle and that the liver and kidney showed the lowest levels of L-carnitine synthesis organ in the data of various animals. The present results agreed with this tendency; the muscle had the highest L-carnitine content among blood and tissues. Tsuneishi et al. [3] reported that a reduction in energy intake of grazing of cows increased the L-carnitine synthesis rate because a high content of L-carnitine was detected in loin. Presently, the L-carnitine content in the femoral muscle slightly decreased after the 1/3 nitrogen replacement, though it was not statistical different. Therefore, the de novo synthesis of L-carnitine was not affected by the nitrogen replacement of the diet for the rabbits. The nitrogen replacement of the diet in the present experiment may not appreciably affect nitrogen metabolism, because there was no significant difference in the blood urea content. This finding suggests that there was no degradation of body protein for the amino acid supply.

It was concluded that the nitrogen replacement of diet with urea in the range of $1 / 3$ of dietary protein had no effect on the maintenance of body weight and nitrogen balance, including the de novo synthesis of L-carnitine for the rabbits.

\section{Acknowledgements}

Author sincerely thanks Mr. T. Murakami for his valuable assistance in conducting this work.

\section{References}

[1] Sukemori, S., Odo, S. and Ikeda, S. (2016) Effects of L-Carnitine Supplementation on Growth Performance and Fatty Acid Proportion in Epididymal Adipose Tissue of Rats Fed Diets Containing Fat from Different Sources. Journal of Veterinary Science and Medical 
Diagnosis, 5, 1 .

[2] Sukemori, S., Odo, S. and Ikeda, S. (2016) Dietary Supplementation with L-Carnitine Induces Equal Utilization of Long-Chain Fatty Acids for Energy Production in Rats Trained with Walking. Journal of Veterinary Science and Medical Diagnosis, 5, 4.

[3] Tsuneishi, E. (2004) Beef of Grazing Cow Includes High Level of L-Carnitine. Kanto Journal of Animal Science, 55, 69-73.

[4] Sukemori, S., Ikeda, S., Kurihara, Y. and Ito, S. (2002) Amino Acid, Mineral and Vitamin Levels in Hydrous Faeces Obtained from Coprophagy-Prevented Rats. Journal of Animal Physiology and Animal Nutrition, 87, 213-220. https://doi.org/10.1046/j.1439-0396.2003.00415.x

[5] Sukemori, S., Kurosawa, A., Ikeda, S. and Kurihara, Y. (2006) Investigation on the Growth of Coprophagy-Prevented Rats with Supplemented Vitamin $\mathrm{B}_{12}$. Journal of Animal Physiology and Animal Nutrition, 90, 402-406. https://doi.org/10.1111/j.1439-0396.2006.00619.x

[6] Abe, Y., Sakoda, T., Goto, H., Ikeda, S. and Sukemori, S. (2014) Cecotrophy Contributes Methionine and Threonine Requirements of Rabbits. Journal of Japanese Pet Animal Nutrition, 17, 6-12.

[7] Goto, M. and Takahashi, N. (1978) Effect of NPN Supplementation on the Protein Contents in Cecum of Rabbits and Nitrogen-Balance under the Coprophagy-Prevented Condition. Bulletin of the Department of Agriculture, Meiji University, 45, 1-6.

[8] National Research Council (1977) Nutrient Requirements of Rabbits. National Academy Science, Washington DC.

[9] Casillas, E.R. and Chaipayungpan, S. (1982) Carnitine Content of Rabbit Epididymal Spermatozoa in Organ Culture. Journal of Reproduction and Fertility, 65, 247-251. https://doi.org/10.1530/jrf.0.0650247

[10] Madeleine, E.M. (1978) Carnitine Metabolism in Human Subjects 1. Normal Metabolism. The American Journal of Clinical Nutrition, 31, 293-306.

[11] Curto, M., Piccinni, M., Mioletti, S., Bruno, R., Ricciardi, M.P. and Rinaudo, M.T. (1994) Levels of Carnitine and Glycogen in Rabbit Tissues during Development. The International Journal of Biochemistry, 26, 163-169. https://doi.org/10.1016/0020-711X(94)90141-4

[12] Oluokun, J.A. (2005) Intake, Digestion and Nitrogen Balance of Diets Blended with Urea Treated and Untreated Cowpea Husk by Growing Rabbit. African Journal of Biotechnology, 4, 1203-1208.

[13] Mohammed, M. and Jamala, G.Y. (2013) Performance and Nutrient Digestibility of Rabbit Fed Urea Treated Cowpea Husk. IOSR Journal of Agriculture and Veterinary Science, 5, 34-37. https://doi.org/10.9790/2380-0523437

[14] Abdl-Rahman, M.A., Saleh, S.Y., Amal, A.Z. and Safaa, S.A.E. (2011) Growth Performance, Cecal Fermentation and Blood Biochemistry of Rabbits Fed Diet Supplemented with UreaBentonite Combination. Journal of Agricultural Science, 3, 14-21. https://doi.org/10.5539/jas.v3n1p14 
Submit or recommend next manuscript to SCIRP and we will provide best service for you:

Accepting pre-submission inquiries through Email, Facebook, LinkedIn, Twitter, etc. A wide selection of journals (inclusive of 9 subjects, more than 200 journals) Providing 24-hour high-quality service

User-friendly online submission system

Fair and swift peer-review system

Efficient typesetting and proofreading procedure

Display of the result of downloads and visits, as well as the number of cited articles Maximum dissemination of your research work

Submit your manuscript at: http://papersubmission.scirp.org/

Or contact ojas@scirp.org 